\title{
Genotoxic evaluation of the antimalarial drugs artemisinin and artesunate in human HepG2 cells and effects on CASP3 and SOD1 gene expressions
}

\author{
I. Aquino ${ }^{1}$, M.S.F. Tsuboy ${ }^{2}$, J.C. Marcarini' ${ }^{2}$, M.S. Mantovani ${ }^{3}$, F.F. Perazzo ${ }^{4}$ \\ and E.L. Maistro ${ }^{1,5}$ \\ ${ }^{1}$ Programa de Pós-Graduação em Biologia Geral e Aplicada, \\ Instituto de Biociências, Universidade Estadual Paulista, Botucatu, SP, Brasil \\ ${ }^{2}$ Programa de Pós-Graduação em Ciências Biológicas (Biologia Celular e Molecular), \\ Instituto de Biociências, Universidade Estadual Paulista, Rio Claro, SP, Brasil \\ ${ }^{3}$ Laboratório de Genética Toxicológica, Universidade Estadual de Londrina, \\ Londrina, PR, Brasil \\ ${ }^{4}$ Departamento de Ciências Exatas e da Terra, \\ Universidade Federal de São Paulo, Diadema, SP, Brasil \\ ${ }^{5}$ Departamento de Fonoaudiologia, Faculdade de Filosofia e Ciências, \\ Universidade Estadual Paulista, Marília, SP, Brasil \\ Corresponding author: E.L. Maistro \\ E-mail: edson.maistro@marilia.unesp.br
}

Genet. Mol. Res. 12 (3): 2517-2527 (2013)

Received February 20, 2013

Accepted June 5, 2013

Published July 24, 2013

DOI http://dx.doi.org/10.4238/2013.July.24.6

\begin{abstract}
The malaria treatment recommended by the World Health Organization involves medicines derived from artemisinin, an active compound extracted from the plant Artemisia annua, and some of its derivatives, such as artesunate. Considering the lack of data regarding the genotoxic effects of these compounds in human cells, the objective of this study was to evaluate the cytotoxicity and genotoxicity, and expressions of the CASP3 and SOD1 genes in a cultured human hepatocellular liver carcinoma cell line (HepG2 cells)
\end{abstract}


treated with artemisinin and artesunate. We tested concentrations of $2.5,5,7.5,10$, and $20 \mu \mathrm{g} / \mathrm{mL}$ of both substances with a resazurin cytotoxicity assay, and the concentrations used in the genotoxicity experiments $(2.5,5$, and $10 \mu \mathrm{g} / \mathrm{mL})$ and gene expression analysis $(5 \mu \mathrm{g} / \mathrm{mL})$ were determined. The results of the comet assay in cells treated with artemisinin and artesunate showed a significant dosedependent increase $(\mathrm{P}<0.001)$ in the number of cells with DNA damage at all concentrations tested. However, the gene expression analysis revealed no significant change in expression of CASP3 or SOD1. Our data showed that although artemisinin and artesunate exhibited genotoxic effects in cultured HepG2 cells, they did not significantly alter expression of the CASP3 and SOD1 genes at the doses tested.

Key words: Artemisinin; Artesunate; HepG2 cells; Gene expression; Comet assay; CASP3 and SOD1 genes

\section{INTRODUCTION}

Many plant extracts and their active components have been described and utilized as therapeutic agents (Verma and Singh, 2008); however, some plants also synthesize toxic substances as a primary defense against hordes of bacteria, fungi, insects, and other predators. Therefore, it is important to assess the genotoxic effects and changes in gene expression caused by medicinal extracts and their isolated compounds.

Artemisinin, a natural sesquiterpene lactone isolated from the plant Artemisia annua, is a widely used drug for treating resistant strains of malaria (Efferth et al., 2001). Artesunate is a semisynthetic derivative of artemisinin that has been accepted as a treatment for malaria (Price, 2000). Artemisinin and its derivative compounds are present in all five of the combined therapies recommended by the World Health Organization (WHO) for the treatment of uncomplicated falciparum malaria (WHO, 2010).

Some in vitro studies using cancer cell lines suggested that artemisinin and some of its derivatives have cytotoxic effects, alter the cell cycle, and induce apoptosis (Hou et al., 2008; Li et al., 2008; Youns et al., 2009; Zhang et al., 2010). These compounds may present cytotoxic activity in mammal cell proliferation (Efferth et al., 2001; Disbrow et al., 2005), and it has been suggested that the toxicity is related to high intracellular concentrations of iron (Smith et al., 1997; Singh and Lai, 2001).

Other studies have indicated that the mechanism of action of antimalarial drugs, including artemisinin and its derivatives, causes damage to membrane structures, which can directly influence normal cell functioning and initiate a series of biochemical reactions resulting in cell death (Olliaro and Taylor, 2004; Sato et al., 2007). In addition, it has been shown that endoperoxides of artemisinin trigger the production of reactive oxygen species (ROS), which has also been implicated in the mechanism of cytotoxicity (Disbrow et al., 2005). Embryotoxicity has been observed in rats and rabbits (Clark et al., 2004; Longo et al., 2006), and neurotoxicity has been observed both in vitro and in vivo (Schmuck et al., 2002). 
Reports on mammalian cell genotoxicity are scarce for artesunate. Aquino et al. (2011) reported genotoxic effects of artesunate in liver cells of mice at low doses and clastogenic effects at high doses in bone marrow cells of the same animals. Li et al. (2008) and Mota et al. (2011) reported genotoxic and cytotoxic effects of artesunate in vitro in Chinese hamster ovary cells and in human peripheral lymphocytes, respectively. To the best of our knowledge, no genotoxic studies on mammalian cells of artemisinin and no genotoxic studies on metabolizing cells of artemisinin and artesunate have been carried out.

Cell death is obligatory for harmonious cell life in animals for the removal of infected, injured, or cancerous cells, and caspases are usually involved in this apoptotic process (Denault and Salvesen, 2002). Considering that ROS play important roles in the pathogenesis of many diseases, and that superoxide dismutases (SODs) are the major antioxidant defense systems against ROS (Fukai and Ushio-Fukai, 2011), it is important to evaluate expression of these genes when cells are exposed to new chemicals in order to better evaluate the cytotoxicity of these compounds.

Because artemisinin and artesunate are widely used drugs, with more than 100 million doses administered annually (WHO, 2010), it is essential to develop studies examining their genotoxic potential and to determine the molecular mechanisms of their cytotoxicity in order to evaluate their safe and effective use for malaria and their potential use in cancer treatment. By exposing human hepatocellular liver carcinoma (HepG2) cells to artemisinin and artesunate in vitro, this study evaluated both the cytotoxic and genotoxic effects of these compounds on mammalian DNA, as well as expressions of the caspase 3 (CASP3) and SOD1 genes to obtain more information about its genotoxic mechanism.

\section{MATERIAL AND METHODS}

\section{Artemisinin and artesunate}

The leaves of $A$. annua L. were collected in the experimental field of medicinal plants of Multidisciplinary Research Chemical, Biological and Agricultural Center (CPQBA) - UNICAMP - in the town of Paulínia, SP. A voucher specimen was deposited in the herbarium of CPQBA (CPQBA 12.46). Leaves (5000 g) of A. annua were oven dried at $40^{\circ} \mathrm{C}$, pressed, and extracted by maceration with $20 \mathrm{~L}$ hexane for 2 days. The macerated sample was filtered and concentrated under reduced pressure, providing 92 g crude extract hexane (1.84\% yield). The artemisinin purification was conducted in chromatography columns using silica gel $60230-400$ mesh (0.040-0.063 mm particulates). Elution of sample components was achieved by incorporating the material with a mixture of n-hexane:ethyl acetate (9:1). The same mobile phase was used to run the column and the successive fractions obtained were monitored by thin layer chromatography. After purification of the sample, crystallization of the artemisinin was performed with selected solvents (Cafferata et al., 2009). Colorless crystals, with the typical characteristic of long needles, were obtained for a total of $16.4 \mathrm{~g}$ artemisinin $(0.33 \%$ yield). The analysis was confirmed by nuclear magnetic resonance, whose spectra were obtained in a Bruker device DPX $400 \mathrm{MHz}$, operating at $400 \mathrm{MHz}$ for $\left[{ }^{1} \mathrm{H}\right]$ and at $100 \mathrm{MHz}$ to $\left[{ }^{13} \mathrm{C}\right]$. The samples were dissolved in deuterated chloroform ( $\mathrm{CDCl}_{3}$, Sigma-Aldrich Co.).

Dihydroartemisinin (DHA) was prepared from artemisinin using a routine proce- 
dure (Brossi et al., 1988). The chloride acid RCOCl was prepared from the corresponding carboxylic acids by heating with thionyl chloride at $55^{\circ} \mathrm{C}$ for $3 \mathrm{~h}$ and reacting with DHA in the presence of triethylamine in dry dichloromethane at $0^{\circ} \mathrm{C}$ for $2 \mathrm{~h}$ to furnish ester derivatives in $49-58 \%$ yields. Artesunate was prepared from DHA by reacting it with succinic acid anhydride in basic medium. Pyridine was used as the solvent, sodium bicarbonate as the base, and $N, N$-dimethylaminopyridine and triethylamine in 1,2-dichloroethane were used as catalysts, with yields of up to $100 \%$. The mixture was stirred for up to $9 \mathrm{~h}$ to obtain artesunate in quantitative yield. The product was further re-crystallized from dichloromethane. Alpha-artesunate was exclusively formed (melting point $=135^{\circ}-137^{\circ} \mathrm{C}$ ). The purity of both compounds was estimated at $99 \%$ by both high performance liquid chromatography and spectral data analysis.

\section{Cell line}

The human hepatoma cell line HepG2 used in our study was obtained from the Cell Bank of Rio de Janeiro (UFRJ), Rio de Janeiro, RJ, Brazil. Cells were cultivated in minimum essential media (Gibco) supplemented with 10\% fetal bovine serum (Gibco) and antibiotics (Gibco), at $37^{\circ} \mathrm{C}, 5 \% \mathrm{CO}_{2}$, and $95 \%$ relative humidity.

\section{Cytotoxicity evaluation: resazurin-based assay}

Since 1995, several studies have used resazurin as an indicator of cell viability (Yajko et al., 1995). In our experiments, we tested artemisinin and artesunate at concentrations chosen according to the available literature: $2.5,5,7.5,10$, and $20 \mu \mathrm{g} / \mathrm{mL}$. The tests were done in biological duplicate with three repetitions each. Approximately $5 \times 10^{4}$ cells were seeded in each well of a 24-well microplate. After $24 \mathrm{~h}$ stabilization, cells were treated with the concentrations of artemisinin or artesunate described above, as well as with $2 \mu \mathrm{g} /$ $\mathrm{mL}$ doxorubicin as a positive control, for $24 \mathrm{~h}$. At the end of this period, the medium was removed, cells were washed with phosphate-buffered saline, and cells were incubated with $60 \mu \mathrm{M}$ resazurin (Acros Organics) for $3 \mathrm{~h}$. Fluorescence was measured with VICTOR 3 (Perkin Elmer) at 530-560 $\mathrm{nm}$ of excitation and a 580-600-nm emission range.

\section{Comet assay}

The comet test was carried out based on conditions described in Tice et al. (2000). One million cells were seeded for each experimental flask and, after $24 \mathrm{~h}$ stabilization, they were treated with artemisinin or artesunate at concentrations of $2.5,5$, and $10 \mu \mathrm{g} / \mathrm{mL}$ for $3 \mathrm{~h}$. The positive control concentration chosen was $2 \mu \mathrm{g} / \mathrm{mL}$, since it requires metabolization to exert genotoxic effects. After this, cells were trypsinized (500 $\mu \mathrm{L} 0.1 \%$ trypsinEDTA, $\left.37^{\circ} \mathrm{C}\right)$, the cell suspension was centrifuged ( $\left.5 \mathrm{~min}, 1000 \mathrm{rpm}\right)$, and the pellet was resuspended in $500 \mu \mathrm{L}$ culture medium. Next, $120 \mu \mathrm{L}$ low melting point agarose $(0.5 \%)$ was added to the cells, this mixture was deposited on pregelatinized slides $(1.5 \%$ normal melting point agarose), and placed in lysis solution for at least $1 \mathrm{~h}$. After denaturation (20 $\mathrm{min}$ ) and alkaline electrophoresis (25 V, $300 \mathrm{~mA}, 40 \mathrm{~min})$, the slides were neutralized, fixed, and kept refrigerated until analysis. The slides were stained with ethidium bromide 
and were analyzed visually (Kobayashi, 1995) under a fluorescence microscope (excitation filter of 420-490 nm and emission filter of $520 \mathrm{~nm}$ ) at $400 \mathrm{X}$ magnification. The comets were classified as follows: class 0 , nucleus without tail; class 1 , nucleus with tail less than the diameter of the nucleus; class 2 , nucleus with tail 1 to 2 times the diameter of the nucleus; class 3, nucleus with tail more than 2 times the diameter of the nucleus. Experiments were performed in triplicate, and 300 cells were analyzed per treatment. Determination of cell viability was carried out by the trypan blue exclusion method, where only treatments with greater than $80 \%$ viability were considered.

\section{Quantitative real-time polymerase chain reaction (qRT-PCR)}

For analysis of gene expression, $10^{6}$ cells were seeded in each experimental culture flask. After $24 \mathrm{~h}$ stabilization, cells were treated with $5 \mu \mathrm{g} / \mathrm{mL}$ artemisin or artesunate for $12 \mathrm{~h}$. Experiments were performed in duplicate.

Total RNA extraction was performed using the Trizol LS reagent (Invitrogen) according to manufacturer instructions. DNAse I (Invitrogen) treatment was also performed according to manufacturer instructions. RNA quality was verified on agarose gel (28S and $18 \mathrm{~S}$ rRNA pattern of bands) and by the $\mathrm{A}_{260} / \mathrm{A}_{280}$ ratio. The cDNA was synthesized with $10 \mathrm{pmol} / \mathrm{mL}$ oligo-dT primer and M-MLV reverse transcriptase (Invitrogen), and stored at $-80^{\circ} \mathrm{C}$ until use in qRT-PCR experiments. qRT-PCR runs were performed in an Engine Opticon detection system (Bio-Rad) using the Platinum ${ }^{\circledR}$ SYBR ${ }^{\circledR}$ Green qPCR SuperMixUDG kit (Invitrogen) under the following conditions: $50^{\circ} \mathrm{C}$ for $1 \mathrm{~min}, 95^{\circ} \mathrm{C}$ for $3 \mathrm{~min}, 35$ cycles of $95^{\circ} \mathrm{C}$ for $20 \mathrm{~s}$ each, $60^{\circ} \mathrm{C}$ for $30 \mathrm{~s}$, and $72^{\circ} \mathrm{C}$ for $20 \mathrm{~s}$. The melting curve varied from 50 to $95^{\circ} \mathrm{C}$, ready every $0.5^{\circ} \mathrm{C}$. Data were normalized with the GAPDH primer (Sugaya et al., 2005), which was amplified in each run of PCR. The primer sequence of SOD1 was manufactured according to Ding et al. (2004) and the primer sequence of CASP3 was designed using the IDT tool available at http://www.idtdna.com/Scitools/ Applications/Primerquest: forward 5'- GTGCTACAATGCCCCTGGAT-3' and reverse 5'-GCCCATTCATTTATTGCTTTCC-3'.

\section{Statistical analysis}

After verifying for normal distribution, data obtained from cytotoxicity and single cell gel electrophoresis assays were submitted to one-way analysis of variance (ANOVA) and the Tukey-Kramer multiple comparison test with the GraphPad Instat ${ }^{\circledR}$ software (version 3.01). Results were considered to be statistically significant at $\mathrm{P}<0.05$. Gene expression levels investigated by qRT-PCR were determined according to the Pfaffl (2001) method using the REST-384 software (Pfaffl et al., 2002).

\section{RESULTS}

\section{Cytotoxicity assay (resazurin)}

Results of duplicate resazurin tests indicated that the $7.5,10$, and $20 \mu \mathrm{g} / \mathrm{mL}$ concentrations of artemisinin and artesunate were cytotoxic (Figure 1). Based on these data, 
we chose concentrations of $2.5,5$, and $10 \mu \mathrm{g} / \mathrm{mL}$ for the comet assay, and a concentration of $5 \mu \mathrm{g} / \mathrm{mL}$ for the gene expression analysis.

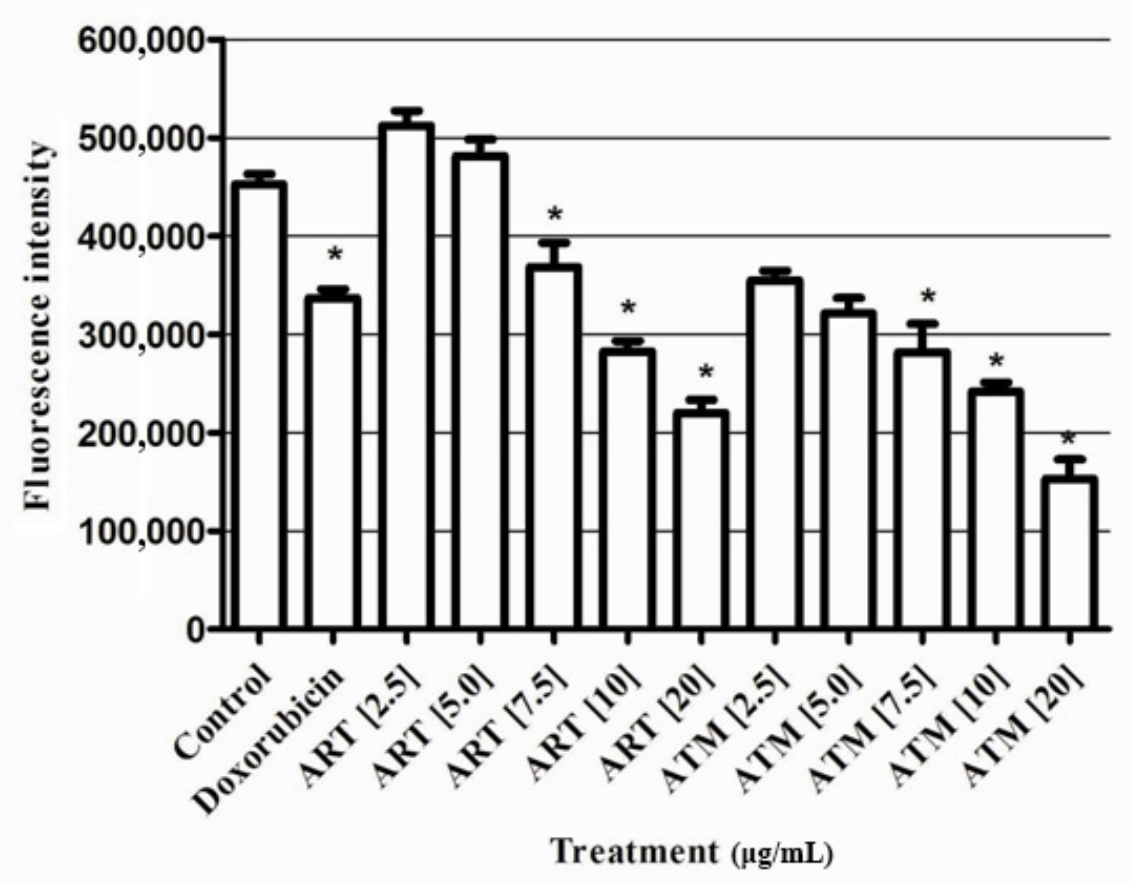

Figure 1. Cytotoxicity of artesunate (ART) and artemisinin (ATM) by the resazurin cytotoxicity assay. *Significantly different from the control $(\mathrm{P}<0.001)$.

\section{Comet assay}

Under the experimental conditions, groups treated with both artemisinin and artesunate had more cells with DNA damage and higher damage scores relative to the negative control group at all three concentrations tested $(\mathrm{P}<0.001)$ (Table 1). For both compounds, the majority of cells that suffered DNA damage showed light to medium damage (classes 1 and 2), with a minority showing severe damage (class 3 ). In general, artemisinin produced a greater number of cells with DNA damage classes 2 and 3 than did artesunate.

\section{Analysis of expression levels of the CASP3 and SOD1 genes}

According to the gene expression analysis, all groups maintained RNA integrity with satisfactory quantity and purity. The qRT-PCR analysis was used to detect changes in expressions of the two studied genes. Expression of CASP3 was slightly increased relative to controls. On the other hand, there was an increase in the expression of SOD1 in cells treated with artemisinin and a decrease in cells treated with artesunate. Nevertheless, the observed differences were not statistically significant (Figure 2). 


\begin{tabular}{|c|c|c|c|c|c|c|}
\hline \multirow[t]{2}{*}{ Treatments } & \multirow[t]{2}{*}{ Total $^{1}$} & \multicolumn{4}{|c|}{ Comet class } & \multirow[t]{2}{*}{ Scores } \\
\hline & & 0 & 1 & 2 & 3 & \\
\hline \multirow{4}{*}{ Control } & 9 & 91 & 8 & 1 & 0 & 10 \\
\hline & 11 & 89 & 9 & 2 & 0 & 13 \\
\hline & 13 & 87 & 10 & 2 & 1 & 17 \\
\hline & $11 \pm 2.0$ & & & & & $13.3 \pm 3.5$ \\
\hline \multirow[t]{4}{*}{$\operatorname{Artemisinin}(2.5 \mu \mathrm{g} / \mathrm{mL})$} & 93 & 7 & 46 & 42 & 5 & 145 \\
\hline & 90 & 10 & 46 & 37 & 7 & 141 \\
\hline & 92 & 8 & 45 & 40 & 7 & 146 \\
\hline & $91.6 \pm 1.5^{*}$ & & & & & $144 \pm 2.6^{*}$ \\
\hline \multirow[t]{4}{*}{$\operatorname{Artemisinin}(5 \mu \mathrm{g} / \mathrm{mL})$} & 90 & 10 & 42 & 35 & 13 & 151 \\
\hline & 95 & 5 & 48 & 38 & 9 & 151 \\
\hline & 91 & 9 & 41 & 39 & 11 & 152 \\
\hline & $92 \pm 2.6^{*}$ & & & & & $151.3 \pm 0.5^{*}$ \\
\hline \multirow[t]{4}{*}{ Artemisinin $(10 \mu \mathrm{g} / \mathrm{mL})$} & 94 & 6 & 42 & 33 & 19 & 165 \\
\hline & 96 & 4 & 46 & 37 & 13 & 159 \\
\hline & 97 & 3 & 38 & 36 & 23 & 179 \\
\hline & $95.6 \pm 1.5^{*}$ & & & & & $167.6 \pm 10^{*}$ \\
\hline \multirow{4}{*}{ Artesunate $(2.5 \mu \mathrm{g} / \mathrm{mL})$} & 52 & 48 & 40 & 12 & 0 & 64 \\
\hline & 62 & 38 & 48 & 14 & 0 & 76 \\
\hline & 70 & 30 & 53 & 16 & 1 & 88 \\
\hline & $61.3 \pm 9.0^{*}$ & & & & & $76 \pm 12 *$ \\
\hline \multirow{4}{*}{ Artesunate $(5 \mu \mathrm{g} / \mathrm{mL})$} & 70 & 30 & 53 & 14 & 3 & 90 \\
\hline & 64 & 36 & 38 & 23 & 3 & 93 \\
\hline & 68 & 32 & 46 & 20 & 2 & 92 \\
\hline & $67.3 \pm 3.0^{*}$ & & & & & $91.6 \pm 1.5^{*}$ \\
\hline \multirow{4}{*}{ Artesunate $(10 \mu \mathrm{g} / \mathrm{mL})$} & 92 & 8 & 41 & 34 & 17 & 160 \\
\hline & 94 & 6 & 31 & 43 & 20 & 177 \\
\hline & 98 & 2 & 29 & 53 & 16 & 183 \\
\hline & $94.6 \pm 3.0^{*}$ & & & & & $173.3 \pm 11.9^{*}$ \\
\hline \multirow{4}{*}{ Doxorubicin $(2 \mu \mathrm{g} / \mathrm{mL})$} & 95 & 5 & 15 & 39 & 41 & 166 \\
\hline & 91 & 9 & 29 & 46 & 16 & 169 \\
\hline & 92 & 8 & 25 & 52 & 15 & 174 \\
\hline & $91 \pm 4.5^{*}$ & & & & & $169.6 \pm 4.0^{*}$ \\
\hline
\end{tabular}

*Significantly different from the negative control $(\mathrm{P}<0.001) .{ }^{1}$ Total number of damaged cells (classes 1,2 , and 3$)$.

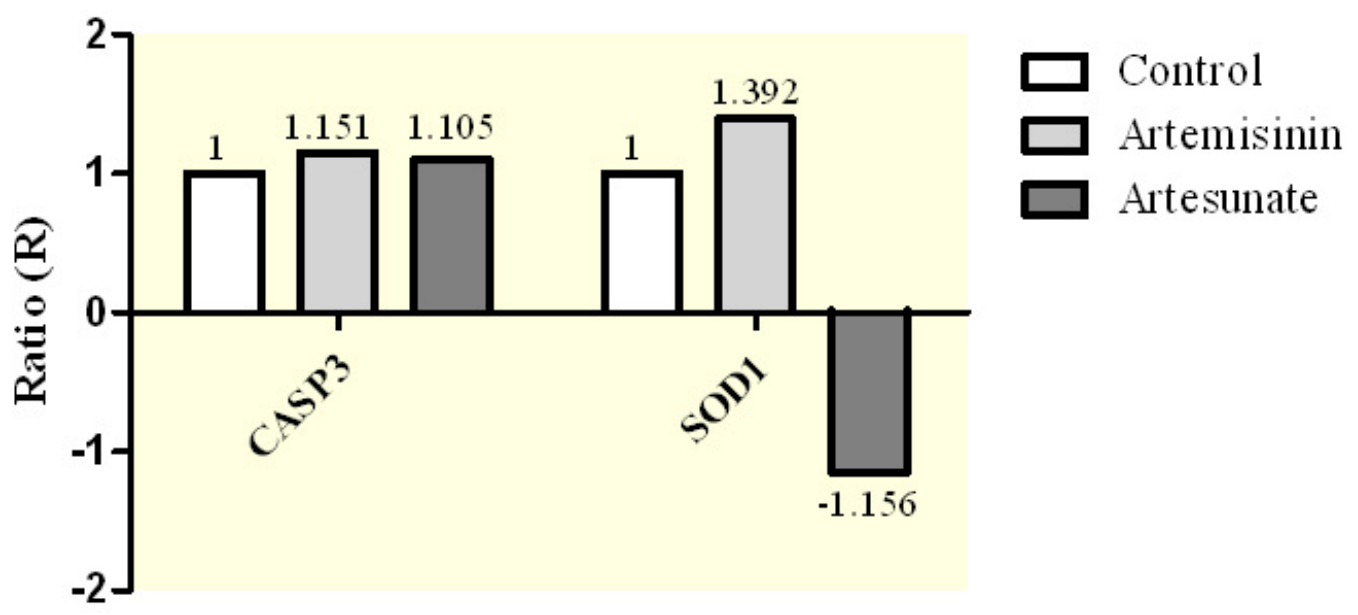

Figure 2. Relative expression of mRNA for CASP3 and SOD1, quantified by real-time PCR in HepG2 cell line. 


\section{DISCUSSION}

Many medicines and environmental factors can cause DNA damage, and experiments analyzing the consequences of exposure to harmful agents are of fundamental importance for the development of medicines and environmental health research. Thus, with respect to artemisinin and artesunate, the presence of a safe balance between their therapeutic and toxicological effects should be verified.

A resazurin cytotoxicity assay was performed to determine the concentrations of artemisinin and artesunate to be tested in the present study. This assay is one of the most widely used methods and is the most sensitive test for detecting in vitro cytotoxicity (Fotakis and Timbrell, 2006). One of the advantages of this test is that it does not only assess cell death, but can also indicate inhibited cell growth, i.e., cytostatic effect. Our results showed that concentrations of $7.5,10$, and $20 \mathrm{mg} / \mathrm{mL}$ artemisinin and artesunate were cytotoxic to HepG2 cells after $24 \mathrm{~h}$ of exposure. Artesunate-induced changes in cell cycle kinetics were observed previously. Veerasubramanian et al. (2006) reported that artesunate, at concentrations lower than those used in the present study, could reduce the proliferation of cultured lymphocytes. Zhou and Feng (2005) reported that artesunate blocked the cell cycle during the G0/G1 phase in vascular smooth muscle cells from the aortas of mice. Electron microscopy of Panc-1, BxPC3, and CFPAC-1 pancreatic cancer cells treated with artesunate revealed organelle destruction and internal disorganization in mitochondria, i.e., selective cytotoxic activity (Du et al., 2010).

In the present study, because the concentrations of 2.5 and $5 \mathrm{mg} / \mathrm{mL}$ artemisinin and artesunate were not cytotoxic to HepG2 cells, we performed the comet assay to verify whether these concentrations caused DNA damage. Results showed that all three concentrations tested of artemisinin and artesunate caused damage in the genetic material of HepG2 cells $(\mathrm{P}<$ 0.001 ), predominantly resulting in damage classes 1 and 2 .

Reports on mammalian cell genotoxicity are scarce for artesunate, and are entirely lacking for artemisinin. Li et al. (2008) analyzed Chinese hamster ovary (CHO-9) and hamster lung fibroblast (V79-2) cell lines with the comet assay and verified that, in vitro, artesunate induced DNA damage and apoptosis. These authors also concluded that in mammalian cells, artesunate generated damage through direct or indirect oxidative stress, resulting in DNA strand breakage. Mota et al. (2011) also reported the genotoxicity of artesunate in human peripheral lymphocytes. The present study confirmed such genotoxicity in vitro for human metabolizing cells, and further studies are necessary to determine whether the generation of ROS could be involved in the genotoxicity of artesunate. Artesunate also showed genotoxic effects in peripheral blood leukocytes and liver cells of mice in vivo (Aquino et al., 2011). Our findings also agree with authors who assessed the genotoxic effects of other sesquiterpenes (Burin et al., 2001; Canalle et al., 2001; Al-Zubairi et al., 2010). In addition to causing DNA damage, the cytotoxicity of these substances, especially artemisinin, is due in part to the decreased expression of topoisomerase 2 (Youns et al., 2009), which is essential for cell proliferation and is expressed in dividing cells (Toyoda et al., 2008).

Using the MTT test, Hou et al. (2008) observed a significant reduction in cell viability in HepG2 cells treated with artemisinin and DHA (1-100 mM), with the percentage of viable cells ranging from 84.7 to $15.5 \%(\mathrm{P}<0.01)$ after $48 \mathrm{~h}$ of exposure. Also in this study, treating HepG2 cells with artemisinin at 10, 25, and $50 \mathrm{mM}$ resulted in greater numbers of G1 phase cells $(67.41,70.72$, and $69.21 \%$, respectively), in comparison with untreated cells. 
Apoptosis is a key regulator of physiological growth control and tissue homeostasis regulation. The methods currently used in clinical oncology and chemotherapy or immunotherapy to bring about the death of tumor cells involve activating apoptosis signal transduction. Hou et al. (2008) reported that artemisinin and artesunate exerted the greatest cytotoxicity on HepG2, inhibiting cell proliferation and inducing apoptosis by activating the CASP 3 gene. Other authors also observed similar effects for both of these compounds ( $\mathrm{Li}$ et al., 2008; Youns et al., 2009; Du et al., 2010; Zhang et al., 2010). We analyzed expression of the CASP3 gene in HepG2 cells after exposure to artemisinin and artesunate because it is the final common pathway of almost all apoptotic pathways. Both compounds caused a slight, although not statistically significant, increase in the expression of this gene, which may suggest that they alter the cell cycle but do not induce apoptosis (Figure 2). This non-significant increase in CASP3 expression may also be due to exposure time (12 h). Youns et al. (2009) observed increased CASP3 expression in experiments with artemisinin, although cells were treated for $6 \mathrm{~h}$.

Due to artemisinin and the relationship of artesunate with oxidative stress induction (Michaelis et al., 2010), we chose to study expression of $\mathrm{Cu} / \mathrm{Zn}$ SOD1. SODs catalyze the dismutation of the superoxide radical $\mathrm{O}_{2}$ into hydrogen peroxide $\left(\mathrm{H}_{2} \mathrm{O}_{2}\right)$ and elemental oxygen $\left(\mathrm{O}_{2}\right)$, and thus provide an important defense against the toxicity of superoxide radicals. Our results showed that, compared to the control group, SOD1 expression increased in cells treated with artemisinin and decreased in those treated with artesunate, although these differences were not statistically significant. In a microarray analysis, Youns et al. (2009) also observed a slight decrease in expression of SOD1 after treating pancreatic cells with artesunate. Since only artemisinin treatment increased SOD1 expression, it is possible that this compound has a greater potential for generating oxidative stress than does artesunate. On the other hand, according to Effert et al. (2003) and Effert and Volm (2005), tumor cells can also present resistance to artesunate due to induced expression of antioxidant genes. This hypothesis should be further investigated.

In conclusion, our results indicated that artemisinin and artesunate are potent genotoxic compounds in human HepG2 cells and that a concentration of $5 \mu \mathrm{g} / \mathrm{mL}$ of these compounds was insufficient to produce significant alterations in CASP3 and SOD1 expressions. Therefore, based on our genotoxicity findings, caution regarding the intake of artemisinin and artesunate is necessary, since both may result in an increased risk of carcinogenesis.

\section{ACKNOWLEDGMENTS}

Research supported by CNPq (\#306544/2006-7) and FAPESP - Fundação de Amparo à Pesquisa do Estado de São Paulo (\#2010/07577-3). We thank Patrícia C. Martins Mello for her technical assistance.

\section{REFERENCES}

Al-Zubairi AS, Abdul AB and Syam MM (2010). Evaluation of the genotoxicity of zerumbone in cultured human peripheral blood lymphocytes. Toxicol. In Vitro 24: 707-712.

Aquino I, Perazzo FF and Maistro EL (2011). Genotoxicity assessment of the antimalarial compound artesunate in somatic cells of mice. Food Chem. Toxicol. 49: 1335-1339.

Brossi A, Venugopalan B, Dominguez Gerpe L, Yeh HJ, et al. (1988). Arteether, a new antimalarial drug: synthesis and 
antimalarial properties. J. Med. Chem. 31: 645-650.

Burim RV, Canalle R, Lopes JL, Vichnewski W, et al. (2001). Genotoxic action of the sesquiterpene lactone centratherin on mammalian cells in vitro and in vivo. Teratog. Carcinog. Mutagen. 21: 383-393.

Cafferata LFR, Jeandupeux R, Rimada RS and Gatti WO (2009). Isolation, characterization and quantification of artemisinin by NMR from Argentinean Artemisia annua L. Boletín Latinoamericano y del Caribe de Plantas Medicinales y Aromáticas 8: 275-281.

Canalle R, Burim RV, Callegari Lopes JL and Takahashi CS (2001). Assessment of the cytotoxic and clastogenic activities of the sesquiterpene lactone lynchnopholide in mammalian cells in vitro and in vivo. Cancer Detect. Prev. 25: 93101.

Clark RL, White TE, Clode A, Gaunt I, et al. (2004). Developmental toxicity of artesunate and an artesunate combination in the rat and rabbit. Birth Defects Res. B Dev. Reprod. Toxicol. 71: 380-394.

Denault JB and Salvesen GS (2002). Caspases: keys in the ignition of cell death. Chem. Rev. 102: 4489-4500.

Ding WQ, Vaught JL, Yamauchi H and Lind SE (2004). Differential sensitivity of cancer cells to docosahexaenoic acidinduced cytotoxicity: The potential importance of down-regulation of superoxide dismutase 1 expression. Mol. Cancer Ther. 3: 1109-1117.

Disbrow GL, Baege AC, Kierpiec KA, Yuan H, et al. (2005). Dihydroartemisinin is cytotoxic to papillomavirus-expressing epithelial cells in vitro and in vivo. Cancer Res. 65: 10854-10861.

Du JH, Zhang HD, Ma ZJ and Ji KM (2010). Artesunate induces oncosis-like cell death in vitro and has antitumor activity against pancreatic cancer xenografts in vivo. Cancer Chemother. Pharmacol. 65: 895-902.

Efferth T, Dunstan H, Sauerbrey A, Miyachi H, et al. (2001). The anti-malarial artesunate is also active against cancer. Int. J. Oncol. 18: 767-773.

Efferth T, Sauerbrey A, Olbrich A, Gebhart E, et al. (2003). Molecular modes of action of artesunate in tumor cell lines. Mol. Pharmacol. 64: 382-394.

Efferth T and Volm M (2005). Glutathione-related enzymes contribute to resistance of tumor cells and low toxicity in normal organs to artesunate. In Vivo 19: 225-232.

Fotakis G and Timbrell JA (2006). In vitro cytotoxicity assays: comparison of LDH, neutral red, MTT and protein assay in hepatoma cell lines following exposure to cadmium chloride. Toxicol. Lett. 160: 171-177.

Fukai T and Ushio-Fukai M (2011). Superoxide dismutases: role in redox signaling, vascular function, and diseases. Antioxid. Redox Signal. 15: 1583-1606.

Hou J, Wang D, Zhang R and Wang H (2008). Experimental therapy of hepatoma with artemisinin and its derivatives: in vitro and in vivo activity, chemosensitization, and mechanisms of action. Clin. Cancer Res. 14: 5519-5530.

Kobayashi H, Sugiyama C, Morikawa Y, Hayashi M, et al. (1995). A comparison between manual microscopic analysis and computerized image analysis in the single cell gel electrophoresis assay. MMS Commun. 3: 103-115.

Li PC, Lam E, Roos WP, Zdzienicka MZ, et al. (2008). Artesunate derived from traditional Chinese medicine induces DNA damage and repair. Cancer Res. 68: 4347-4351.

Longo M, Zanoncelli S, Manera D, Brughera M, et al. (2006). Effects of the antimalarial drug dihydroartemisinin (DHA) on rat embryos in vitro. Reprod. Toxicol. 21: 83-93.

Michaelis M, Kleinschmidt MC, Barth S, Rothweiler F, et al. (2010). Anti-cancer effects of artesunate in a panel of chemoresistant neuroblastoma cell lines. Biochem. Pharmacol. 79: 130-136.

Mota TC, Cardoso PC, Gomes LM, Vieira PC, et al. (2011). In vitro evaluation of the genotoxic and cytotoxic effects of artesunate, an antimalarial drug, in human lymphocytes. Environ. Mol. Mutagen. 52: 590-594.

Olliaro PL and Taylor WR (2004). Developing artemisinin based drug combinations for the treatment of drug resistant falciparum malaria: A review. J. Postgrad. Med. 50: 40-44.

Pfaffl MW (2001). A new mathematical model for relative quantification in real-time RT-PCR. Nucleic Acids Res. 29 : e45.

Pfaffl MW, Horgan GW and Dempfle L (2002). Relative expression software tool (REST) for group-wise comparison and statistical analysis of relative expression results in real-time PCR. Nucleic Acids Res. 30: e36.

Price RN (2000). Artemisinin drugs: novel antimalarial agents. Expert. Opin. Investig. Drugs 9: 1815-1827.

Sato K, Adachi T, Ueda D, Hojo M, et al. (2007). Measurement of local strain on cell membrane at initiation point of calcium signaling response to applied mechanical stimulus in osteoblastic cells. J. Biomech. 40: 1246-1255.

Schmuck G, Roehrdanz E, Haynes RK and Kahl R (2002). Neurotoxic mode of action of artemisinin. Antimicrob. Agents Chemother. 46: 821-827.

Singh NP and Lai H (2001). Selective toxicity of dihydroartemisinin and holotransferrin toward human breast cancer cells. Life Sci. 70: 49-56.

Smith SL, Fishwick J, McLean WG, Edwards G, et al. (1997). Enhanced in vitro neurotoxicity of artemisinin derivatives in the presence of haemin. Biochem. Pharmacol. 53: 5-10.

Sugaya S, Nakanishi H and Tanzawa H (2005). Down-regulation of SMT3A gene expression in association with DNA 
synthesis induction after X-ray irradiation in nevoid basal cell carcinoma syndrome (NBCCS) cells. Mutat. Res. 578: 327-332.

Tice RR, Agurell E, Anderson D, Burlinson B, et al. (2000). Single cell gel/comet assay: guidelines for in vitro and in vivo genetic toxicology testing. Environ. Mol. Mutagen. 35: 206-221.

Toyoda E, Kagaya S, Cowell IG, Kurosawa A, et al. (2008). NK314, a topoisomerase II inhibitor that specifically targets the alpha isoform. J. Biol. Chem. 283: 23711-23720.

Veerasubramanian P, Gosi P, Limsomwong C and Walsh DS (2006). Artesunate and a major metabolite, dihydroartemisinin, diminish mitogen-induced lymphocyte proliferation and activation. Southeast Asian J. Trop. Med. Public Health 37: 838-847.

Verma S and Singh SP (2008). Current and future status of herbal medicines. Vet. World 1: 347-350.

WHO (2010). WHO Calls on Malaria-Endemic Countries to Strengthen Monitoring of Antimalarial Drug Efficacy. Available at [http://www.who.int/mediacentre/news/releases/2010/malaria_20101118]. Accessed November 11, 2010.

Yajko DM, Madej JJ, Lancaster MV, Sanders CA, et al. (1995). Colorimetric method for determining MICs of antimicrobial agents for Mycobacterium tuberculosis. J. Clin. Microbiol. 33: 2324-2327.

Youns M, Efferth T, Reichling J, Fellenberg K, et al. (2009). Gene expression profiling identifies novel key players involved in the cytotoxic effect of Artesunate on pancreatic cancer cells. Biochem. Pharmacol. 78: 273-283.

Zhang S, Chen H and Gerhard GS (2010). Heme synthesis increases artemisinin-induced radical formation and cytotoxicity that can be suppressed by superoxide scavengers. Chem. Biol. Interact. 186: 30-35.

Zhou Z and Feng Y (2005). Artesunate reduces proliferation, interferes DNA replication and cell cycle and enhances apoptosis in vascular smooth muscle cells. J. Huazhong. Univ. Sci. Technol. Med. Sci. 25: 135-6, 177. 